\title{
Recipe Standardization and Storability of Jamun RTS with Alternative Sweetners
}

\author{
Bhawna Panda ${ }^{1}$, H.G. Sharma ${ }^{1}$ and Abhay Bisen ${ }^{2 *}$ \\ ${ }^{1}$ Department of Fruit Science, College of Agriculture, IGKV, Raipur-492012, India \\ ${ }^{2}$ SKS College of Agriculture, Rajnandgaon, IGKV-441491, India \\ *Corresponding author
}

\begin{abstract}
A B S T R A C T
The investigation entitled recipe standardization and storability of jamun RTS with alternative sweeteners was conducted at the Horticulture Processing Laboratory,

Keywords

Alternative sweeteners, Jamun, RTS, Storage period, Erythritol, Stevia, Asparatme

Article Info

Accepted:

12 December 2018

Available Online:

10 January 2019

Department of Fruit Science, College of Agriculture, IGKV, Raipur (C.G.) during the year 2015-16. The experimental material consisted of 15 treatments of alternative sweeteners and one treatment of $100 \%$ sugar combination for RTS. The treatments were replicated three times in Completely Randomized Design (CRD). In the experiment alternative sweeteners like Erythrtol, Stevia and Equal were used for the preparation low calorie jamun RTS beverages. Biochemical parameters viz. TSS, ascorbic acid, acidity, nonreducing sugar, reducing sugar, total sugar and organoleptic attributes viz. colour and appearance, aroma, taste and overall acceptability were evaluated at an interval of 30 days from 0 to 90 days of storage period. Among various recipe tried in this investigation, preparation of RTS with treatment $\mathrm{T}_{11}(50 \%$ Equal+ $50 \%$ Sugar) was found to be best followed by $\mathrm{T}_{0}(100 \%$ Sugar). Ascorbic acid and non-reducing sugar was recorded maximum under the treatment $\mathrm{T}_{11}(50 \%$ Equal+ 50\% Sugar) whereas acidity, total sugar and reducing sugar were recorded maximum under the treatment $\mathrm{T}_{5}$ (100\% Stevia). However, in the term of sensory quality treatment $\mathrm{T}_{11}(50 \%$ Equal+ $50 \%$ Sugar) scored maximum.

Introduction

Jamun (Syzygium cumini (L.) Skeels) is an evergreen tropical tree which belongs to family Myrtaceae. Jamun/Black plum fruits are rich in vitamins, minerals and carbohydrates (Sharma et al., 2012). The main phytochemicals found in Jamun fruit are anthocyanins, tannins and other phenolic compounds. Anthocyanins have shown antagonistic activity to some bacteria, virus and fungi and also protect food from

microbial spoilage (Chattopadhyay et al., 2008). Jamun has almost an exotic flavor and are known for their nutritional and therapeutic values. Jamun fruits, although produced in considerable quantities and consumed, but seldom processed. There is a great scope of the processed products not only because of their exotic flavor, but also due to their nutraceutical importance (Kannan and Thiruman, 2002). Thus, processing of jamun fruit into value added products result in a wide variety of exotically flavored products
\end{abstract}


with better nutritional and sensory qualities may unveil new market for export. Therefore, development, standardization and popularization of value-added products from jamun fruits are essential.

RTS is one of the refreshing beverages having zero carbonation, relatively few preservatives and excellent source of several important vitamins and minerals and is used as health drink. Therefore, it is necessary to utilize jamun for making nutritious processed health food like RTS to increase availability over an extended period and to stabilize the price during the glut season. Today's consumers expect more and more pleasure from food. They want to drink such type of beverages which should be lower in fat and sugar. These facts resulted in development of sugar free as low calorie sweeteners (Livesey, 2006). Therefore, fruit beverages can be made with lower calorie sugar like Stevia, Erythritol and Equal etc.

The development of products containing low calorie sweeteners could therefore allow consumers to enjoy sweet foods and drinks with fewer calories. Due to properties of low blood glucose response, low energy value alternative sweetners have been considered as good sugar substitutes in food applications, especially in beverages which are the primary sources for sugar (Maguire, 2006). Studies show that erythritol is tooth-friendly and does not contribute to dental problems like sugar does. Stevia (Stevia rebaudiana, Bert.) is an herb, belongs to the family Asteraceae (Compositae) that grows in North and South America that's 250 times sweeter than sugar. Stevia has no known adverse effects on blood sugar. Aspartame is the ingredient found in NutraSweet. It is also found in Equal, Spoonful, Equal Measure, AminoSweet, Benevia, NutraTaste, Canderel, and many popular "diet" foods and beverages. Alternative sweeteners in its original combination are not easily available in the market for common people. Secondly, it is difficult to calculate the exact quantity as per recipe requirement from the formulation available in the market. Therefore these alternative sweeteners were taken as they are available in the market as per their trade name. Considering the above facts, an investigation had been conducted to see the effect of natural and artificial sweetners on recipe standardization and shelf life of RTS beverages.

\section{Materials and Methods}

The present investigation was conducted in the Horticulture Processing Laboratory Department of Fruit Science, College of Agriculture, Indira Gandhi Agricultural University, Raipur (C.G.) during the year 2015-16. For the experimentation, fullyripened and uniform sized fruits of jamun were procured from the market. Unripe, diseased, damaged and off type fruits were strictly discarded. The selected fruits were thoroughly washed with clean tap water to remove dirt and dusts particles adhered to the pericarp of the fruit and then allowed to dried for removal of excess moisture from the fruit surface, otherwise it permits the entry for harmful micro-organism and prone to spoilage during storage. One kilogram ripened jamun fruits were crushed manually with hands without damaging the seeds. The extracted pulp without seeds was heated to $50^{\circ} \mathrm{C}$ and passed through a fine muslin cloth. After extraction of juice, 10 per cent pulp for RTS was taken. The volume of the final product was maintained by adding water to each recipe combination in each replication. A calculated amount of sugar and alternative sweeteners was added in the juice to adjust the total soluble solids as $15 \%$ for RTS. The acidity was maintained to $0.3 \%$ in the final product by the addition of required amount of citric acid. The prepared RTS beverages were 
again filtered by sieving through a muslin cloth to obtain a product of uniform consistency. The product was poured into hot, sterilized bottles of $200 \mathrm{ml}$ capacity and corked air-tight. The filled bottles were pasteurized in boiling water till the temperature of product reaches $100^{\circ} \mathrm{C}$. It took about 15 minutes to attain required temperature. The bottles of RTS beverages were kept at ambient condition for further studies upto 90 days.

The experiment consists of 15 treatment of alternative sweetener and one treatment of $100 \%$ sugar combination each for nectar and RTS. The experiment consists of 16 treatments of natural and artificial alternative sweeteners with different level of sugar combinations namely, $100 \%$ Erythritol, $75 \%$ Erythritol $+25 \%$ Sugar, 50\% Erythritol + $50 \%$ Sugar, $25 \%$ Erythritol $+75 \%$ Sugar, $100 \%$ Stevia, $75 \%$ Stevia $+25 \%$ Sugar, $50 \%$ Stevia $+50 \%$ Sugar, $25 \%$ Stevia $+75 \%$ Sugar, 100\% Equal (Aspartame), 75\% Equal $+25 \%$ Sugar, $50 \%$ Equal $+50 \%$ Sugar, $25 \%$ Equal $+75 \%$ Sugar, 50\% Erythritol + $50 \%$ Stevia, $50 \%$ Erythritol $+50 \%$ Equal, $50 \%$ Stevia $+50 \%$ Equal and $100 \%$ Sugar for the preparation of nectar beverages.

Ten RTS beverages bottles were taken for each treatment in each replication. The effect of alternative sweetners on chemical composition and organoleptic values of jamun RTS were observed on same day and after 30 , 60 and 90 days of storage at ambient conditions $\left(25^{\circ} \mathrm{C}\right.$ and $\left.60-70 \%\right)$. The acidity, ascorbic acid (mg/100ml), total sugar, reducing and non-reducing sugar were determined as per the method of AOAC (2002). The TSS of fruit was measured with the help of Hand-Refractometer of 0-32 Brix range. The taste, flavor and colour of each sample were evaluated by panel of 10 judges following the nine point Hedonic rating test as described by Ranganna (1997).

\section{Results and Discussion}

\section{Total soluble solids (\%)}

It is clear from the data that total soluble solids content in jamun RTS showed an increasing trend with increasing period of storage (0 to 90 days) in Table 1 . The total soluble solids content of RTS was found to be significant from 0 to 90 days of storage. At the time of preparation, TSS was found significantly higher $(15.05 \%)$ with the treatment $100 \%$ Sugar followed by $25 \%$ Stevia $+75 \%$ Sugar and $25 \%$ Erythritol + $75 \%$ Sugar. While it was significantly minimum $(1.42 \%)$ with the treatment $100 \%$ Stevia. At 30, 60 and 90 days of storage, the total soluble solids content was found to be significantly maximum under the treatment $100 \%$ Sugar. While, significantly minimum TSS content was recorded with the treatment $100 \%$ Stevia.

The increased TSS in RTS during storage was probably due to conversion of polysaccharides into soluble sugars. Similar results were also reported Kananand Thirumaran (2002), Das (2009) and Gehlot et al., (2010) in jamun RTS and Yadavet al., (2012) in banana RTS.

\section{Ascorbic acid (mg/100ml)}

It is apparent from the data that ascorbic acid content in jamun RTS of all the treatments showed a decreasing trend with increasing period of storage (0 to 90 days). A significant difference in ascorbic acid was observed at the time of preparation. It was found to be significant from 0 to 90 days of storage. At the time of preparation, ascorbic acid was significantly higher $(12.68 \mathrm{mg} / 100 \mathrm{ml})$ with the treatment $50 \%$ Equal+50\% Sugar followed by $100 \%$ Sugar and $50 \%$ Erythritol $+50 \%$ Sugar (Table 1). While significantly minimum ascorbic acid content $(12.01 \mathrm{mg} / 100$ 
ml) was recorded with the treatment $100 \%$ Stevia. Thereafter, at 30,60 and 90 days of storage, the level of ascorbic acid decreased and was recorded to be significant. At 30, 60 and 90 days of storage, significantly maximum ascorbic acid content was observed with the treatment $50 \%$ Equal $+50 \%$ Sugar. While, significantly minimum ascorbic acid content was recorded with the treatment $100 \%$ Stevia.

The decrease in ascorbic acid in RTS during storage might be due to oxidation or irreversible conversion of L-ascorbic acid into dehydro ascorbic acid in the presence of enzyme ascorbinase ascorbic acid oxidase caused by trapped or residual oxygen in the glass bottles. The present findings are in accordance with the view of Das (2009) who reported that ascorbic acid content in jamun RTS beverage decreased continuously during entire period of storage. The range of decrease in RTS beverage was found from 12.21 to 10.20. Gaikwad et al., (2012) reported that a reducing trend was observed in ascorbic acid in RTS beverage prepared by blending aonla and ginger juice with Aspartame alternative sweetener. Similar reduction in ascorbic acid content have also been reported by Saravanan et al., (2004) in papaya RTS and by Sharma et al., (2009a) in guava-jamun RTS.

\section{Acidity (\%)}

It is evident from the data that acidity of jamun RTS showed an increasing trend with increasing period of storage (0 to 90 days). At the time of preparation ( 0 days), though the differences were non-significant, however, it was recorded maximum $(0.35 \%)$ under the treatment $100 \%$ Stevia and it was minimum $(0.29 \%)$ with the treatment $50 \%$ Equal $+50 \%$ Sugar. Similarly during 0 to 30 days ofstorage, maximum acidity $(0.36 \%)$ was recorded with the treatment $100 \%$ Stevia and it was minimum $(0.31 \%)$ in the treatment $50 \%$ Equal $+50 \%$ Sugar. The acidity of RTS was found to be significant at 60 and 90 days of storage. At 60 and 90 days of storage, significantly higher acidity was recorded with the treatment $100 \%$ Stevia. While significantly minimum acidity was observed with $50 \%$ Equal $+50 \%$ Sugar (Table 1) .

The increase in acidity in RTS during 60 and 90 days of storage may be due to formation of organic acids by ascorbic acid degradation as well as progressive decrease in the pectin content. The result was in close accordance with the finding of Das (2009) who observed increase in acidity during six months of storage from 0.30 to 0.46 percentages. Gaikwad et al., (2012) reported that a increasing trend was observed in acidity in RTS beverage prepared by blending aonla and ginger juice with aspartame alternative sweetener. Similar findings were also reported by Byanna and Gowda (2012) in sweet orange beverages, Yadav et al., (2012) in banana RTS beverage. Sasikumar (2013) reported that the increasing trend in acidity during the storage of beverages at room temperature over a period of 60 days. Gaikwad et al., (2012) also observed that increasing trend was observed in acidity content during the storage of beverage at room temperature over a period of 60 days.

\section{Reducing sugar (\%)}

The reducing sugar was recorded to be significant effect from 0 to 90 days of storage. At the time of preparation, significantly maximum reducing sugar $(3.56 \%)$ was observed with the treatment $100 \%$ Stevia followed by $50 \%$ Stevia $+50 \%$ Equal and $50 \%$ Erythritol $+50 \%$ Equal. The significantly minimum reducing sugar $(2.44 \%)$ was recorded with the treatment $50 \%$ Equal $+50 \%$ Sugar (Table 2). At the time of 30, 60 and 90 days storage, significantly 
maximum reducing sugar was observed with the treatment $100 \%$ Stevia. It was significantly minimum under the treatment $50 \%$ Equal $+50 \%$ Sugar.

The increase in sugars during storage may be attributed due to gradual inversion of nonreducing sugars to the reducing sugars by the hydrolysis process. These results are in close conformity with the report of Patil (2001) who reported that there was a significant increase in reducing sugars in jamun juice throughout the storage period. Kannan and Thirumaran (2002) reported that reducing sugar content of jamun product increased during 6 months of storage period.

The increase was ranged from 9.7 to 16.5 per cent in RTS, 18.3 per cent to 23.5 per cent in squash, 39.4 per cent to 46.6in syrup and 30.1 per cent to 36.5 per cent in jam. Nidhi et al., (2007) reported that total sugars and reducing sugars increased, while, total phenols decreased in both the beverages with the increase in storage duration.

\section{Non-reducing sugar (\%)}

The non-reducing sugar in jamun RTS showed a decreasing trend with increasing period of storage (0-90 days). The nonreducing sugar was found to be significant from 0 to 90 days of storage. At the time of preparation, significantly maximum non reducing sugar $(10.71 \%)$ was recorded with the treatment $50 \%$ Equal $+50 \%$ Sugar followed by $100 \%$ Sugar and 50\% Erythritol $+50 \%$ Sugar. Whereas, it was significantly minimum under $(10.21 \%)$ the treatment $100 \%$ Stevia which is followed by $50 \%$ Stevia + $50 \%$ Equal. After 30, 60 and 90days of storage, significantly maximum non-reducing sugar was observed with the treatment $50 \%$ Equal $+50 \%$ Sugar. Whereas, significantly minimum non-reducing sugar was recorded with the treatment $100 \%$ Stevia (Table 2).
These results are in close conformity with the report of Saravanan et al., (2004) who reported that the decrease in sucrose content in papaya RTS was correlated with an increase in storage temperature which showed maximum increase in reducing sugar content, whereas, the non-reducing sugar followed a decreasing trend. Similar findings were also reported by Phalke (2009) in sapota-lime blended RTS and Byanna and Gowda (2012) in sweet orange RTS beverages.

\section{Total sugar}

The total sugar content of RTS was found to be significant from 0 to 90 days of storage. At the time of preparation, total sugar was found significantly higher $(13.77 \%)$ with the treatment $100 \%$ Stevia followed by $50 \%$ Stevia $+50 \%$ Equal and 50\% Erythritol + $50 \%$ Equal. The significantly minimum total sugar $(13.15 \%)$ was recorded with the treatment 50\% Equal + 50\% Sugar. At 30, 60 and 90 days of storage, significantly maximum total sugar content was observed with the treatment $100 \%$ Stevia. The significantly minimum total sugar was recorded with the treatment $50 \%$ Equal $+50 \%$ Sugar (Table 2).

The increase in reducing sugar as well as total sugar corresponded to the increase in TSS (total soluble soilds) and ultimate decrease in non reducing sugar in both the beverages during storage period. The variation in different fractions of sugar might be due to hydrolysis of polysaccharides like starch pectin and inversion of non reducing sugar into reducing sugar, as increase in reducing sugar was co-related with the decrease in non reducing sugar. The increased level of total sugar was probably due to conversion of starch and pectin into simple sugars. The results are in conformity with the findings of Gehlot et al., (2010) in jamun juice and beverages. Similar results were also reported 
by Verma and Gehlot (2006) in Bael beverages and Patil et al., (2014) in rose apple jamun blended RTS.

\section{Colour and appearances}

The score for colour and appearances of different treatments were recorded at $0,30,60$ and 90 days and observed that organoleptic score for colour and appearances continuously decreased with all the treatments upto 90 days storage in Table 3. At the time of preparation, significantly maximum score (8.13) was recorded with the treatment $50 \%$ Equal $+50 \%$ Sugar followed by $100 \%$ Sugar and $50 \%$ Erythritol $+50 \%$ Sugar. The significantly minimum score (7.32) was recorded with the treatment $100 \%$ Stevia. After 30, 60 and 90 days of storage, significantly maximum mean score for colour and appearances was recorded with the treatment $50 \%$ Equal $+50 \%$ Sugar. The significantly minimum score was recorded with the treatment $100 \%$ Stevia.

The colour and appearances showed decreasing trend during storage which might be due to the action of acidity which enhances the hydrolytic reaction causes browning and acid also enhances the millard reaction and caramelization which causes more browning in product. Polyphenolic compound present in fruit pulp also reacts with enzymes to get discoloration.

The results are in good agreement with the finding of Gehlot et al., (2008) who reported that the colour and appearance of jamun beverages decreased significantly with the advancement in storage period. Upale et al., (2010) reported the organoleptic scores for colour and overall acceptability of jamun ready-to-serve was highest (4.2) in the recipe consisting of 14 per cent (pasturised) +0.15 per cent citric acid adjusted to 14 per cent TSS. Similar findings were also reported by Pandey (2004) for guava beverages, Mall and
Tondon (2007) for guava-aonla blended beverage, Kumar et al., (2008) for musambi RTS Beverage.

\section{Aroma}

The score for aroma of jamun RTS influenced by different treatments were recorded at 0,30 , 60 and 90 days and observed that organoleptic score for aroma continuously decreased with all the treatments upto 90 days of storage in Table 3. At the time of preparation, significantly maximum score (7.69) was recorded with the treatment $50 \%$ Equal $+50 \%$ Sugar followed by $100 \%$ Sugar and $50 \%$ Erythritol $+50 \%$ Sugar. The significantly minimum score (7.13) was recorded with the treatment 100\% Stevia. After 30, 60 and 90 days of storage, significantly maximum score for aroma was recorded with the treatment $50 \%$ Equal $+50 \%$ Sugar. The significantly minimum score was recorded with the treatment $100 \%$ Stevia. The results are in good agreement with the finding of Gehlot et al., (2008) who reported that the aroma of jamun beverages decreased significantly with the advancement in storage period.

\section{Taste}

The score for taste of jamun RTS affected by different treatments were recorded at $0,30,60$ and 90 days and observed that organoleptic score for taste continuously decreased with all the treatments upto 90 days of storage in Table 3. At the time of preparation, significantly maximum mean score (8.11) was recorded with the treatment $50 \%$ Equal $+50 \%$ Sugar followed by $100 \%$ Sugar and $50 \%$ Erythritol $+50 \%$ Sugar (T3). The significantly minimum score (7.44) was recorded with the treatment $100 \%$ Stevia. After 30, 60 and 90 days of storage, significantly maximum score for taste was recorded with the treatment $50 \%$ Equal $+50 \%$ Sugar. 
Table.1 Effect of alternative sweeteners on total soluble solids, ascorbic acid and acidity of jamun RTS

\begin{tabular}{|c|c|c|c|c|c|c|c|c|c|c|c|c|c|}
\hline & & & & $(\%)$ & & & rbic ac & (mg/10 & ml) & & Acidi & $v(\%)$ & \\
\hline & & 0 & 30 & 60 & 90 & 0 & 30 & 60 & 90 & 0 & 30 & 60 & 90 \\
\hline 1 & $100 \%$ Sugar & 15.05 & 15.1 & 15.26 & 15.48 & 12.63 & 12.53 & 12.39 & 12.06 & 0.31 & 0.32 & 0.44 & 0.5 \\
\hline 2 & $100 \%$ Erythritol & 1.47 & 1.65 & 1.79 & 1.88 & 12.18 & 12.09 & 11.91 & 11.54 & 0.33 & 0.35 & 0.48 & 0.56 \\
\hline 3 & $75 \%$ Erythritol + & 4.02 & 4.14 & 4.27 & 4.43 & 12.33 & 12.22 & 12.06 & 11.68 & 0.32 & 0.33 & 0.64 & 0.72 \\
\hline 4 & $50 \%$ Erythritol + & 7.56 & 7.6 & 7.69 & 7.79 & 12.59 & 12.48 & 12.34 & 12.00 & 0.31 & 0.32 & 0.5 & 0.58 \\
\hline 5 & $25 \%$ Erythritol + & 11.28 & 11.4 & 11.48 & 11.61 & 12.46 & 12.33 & 12.19 & 11.82 & 0.31 & 0.32 & 0.38 & $\mathbf{0 . 4 3}$ \\
\hline 6 & T5: 100\% Stevia & 1.42 & 1.62 & 1.75 & 1.84 & 12.01 & 11.88 & 11.66 & 11.25 & 0.35 & 0.36 & 0.69 & 0.78 \\
\hline 7 & $75 \%$ Stevia $+25 \%$ & 4.11 & 4.22 & 4.28 & 4.42 & 12.28 & 12.2 & 12.02 & 11.65 & 0.33 & 0.34 & 0.47 & 0.53 \\
\hline 8 & $50 \%$ Stevia $+\mathbf{5 0 \%}$ & 7.59 & 7.65 & 7.74 & 7.82 & 12.55 & 12.44 & 12.28 & 11.95 & 0.32 & 0.33 & 0.6 & 0.68 \\
\hline 9 & $25 \%$ Stevia $+75 \%$ & 11.32 & 11.4 & 11.52 & 11.63 & 12.41 & 12.31 & 12.17 & 11.79 & 0.32 & 0.33 & 0.41 & 0.45 \\
\hline 10 & $100 \%$ Equal & 1.74 & 1.81 & 1.9 & 2.02 & 12.24 & 12.15 & 11.97 & 11.59 & 0.33 & 0.34 & 0.46 & 0.63 \\
\hline 11 & $75 \%$ Equal + & 3.75 & 4.03 & 4.23 & 4.38 & 12.37 & 12.27 & 12.12 & 11.73 & 0.33 & 0.34 & 0.58 & 0.66 \\
\hline 12 & $\mathbf{5 0 \%}$ Equal + $\mathbf{5 0 \%}$ & 7.51 & 7.62 & 7.71 & 7.82 & 12.68 & 12.57 & 12.43 & 12.11 & 0.29 & 0.31 & 0.35 & 0.40 \\
\hline 13 & $25 \%$ Equal $+75 \%$ & 11.25 & 11.3 & 11.38 & 11.54 & 12.5 & 12.39 & 12.23 & 11.88 & 0.32 & 0.33 & 0.45 & 0.6 \\
\hline 14 & $50 \%$ Erythritol + & 1.43 & 1.69 & 1.81 & 1.87 & 12.14 & 12.03 & 11.84 & 11.42 & 0.33 & 0.34 & 0.63 & 0.71 \\
\hline 15 & $50 \%$ Erythritol + & 1.62 & 1.83 & 2.01 & 2.11 & 12.1 & 11.99 & 11.77 & 11.37 & 0.34 & 0.35 & 0.65 & 0.73 \\
\hline 16 & $\mathbf{5 0} \%$ Stevia $+\mathbf{5 0} \%$ & 1.57 & 1.8 & 1.94 & 2.04 & 12.06 & 11.94 & 11.72 & 11.32 & 0.34 & 0.35 & 0.66 & 0.75 \\
\hline & SEm \pm & 0.009 & 0.01 & 0.010 & 0.010 & 0.010 & 0.011 & 0.011 & 0.012 & 0.013 & 0.012 & 0.011 & 0.010 \\
\hline & CD at $5 \%$ & 0.026 & 0.03 & 0.030 & 0.029 & 0.03 & 0.032 & 0.033 & 0.036 & NS & NS & 0.032 & 0.029 \\
\hline
\end{tabular}

NS = Non Significant, DAT $=$ Days After Treatment 
Table.2 Effect of alternative sweeteners on reducing sugar, non-reducing sugar and total sugar of jamun RTS

\begin{tabular}{|c|c|c|c|c|c|c|c|c|c|c|c|c|c|}
\hline \multirow[b]{2}{*}{ S.N } & & \multicolumn{4}{|c|}{ Reducing sugar (\%) } & \multicolumn{4}{|c|}{ Non reducing sugar $(\%)$} & \multicolumn{4}{|c|}{ Total sugar (\%) } \\
\hline & & $\mathbf{0}$ & 30 & 60 & 90 & $\mathbf{0}$ & 30 & 60 & 90 & $\mathbf{0}$ & 30 & 60 & 90 \\
\hline 1 & $100 \%$ Sugar & 2.55 & 2.66 & 2.8 & 2.91 & 10.65 & 10.56 & 10.53 & 10.46 & 13.2 & 13.22 & 13.33 & 13.37 \\
\hline 2 & $100 \%$ Erythritol & 3.28 & 3.36 & 3.55 & 3.66 & 10.31 & 10.25 & 10.18 & 10.10 & 13.59 & 13.61 & 13.73 & 13.76 \\
\hline 3 & $75 \%$ Erythritol + & 3.06 & 3.17 & 3.35 & 3.45 & 10.39 & 10.34 & 10.28 & 10.21 & 13.45 & 13.51 & 13.63 & 13.66 \\
\hline 4 & $50 \%$ Erythritol + & 2.65 & 2.74 & 2.88 & 2.97 & 10.59 & 10.52 & 10.49 & 10.45 & 13.24 & 13.26 & 13.37 & 13.42 \\
\hline 5 & $25 \%$ Erythritol + & 2.84 & 2.96 & 3.14 & 3.24 & 10.49 & 10.43 & 10.35 & 10.29 & 13.33 & 13.39 & 13.49 & 13.53 \\
\hline 6 & T5: 100\% Stevia & 3.56 & 3.67 & 3.81 & 3.91 & 10.21 & 10.12 & 10.06 & 9.98 & 13.77 & 13.79 & 13.87 & 13.89 \\
\hline 7 & $75 \%$ Stevia $+25 \%$ & 3.11 & 3.21 & 3.39 & 3.48 & 10.37 & 10.32 & 10.26 & 10.20 & 13.48 & 13.53 & 13.65 & 13.68 \\
\hline 8 & $\mathbf{5 0 \%}$ Stevia + 50\% & 2.71 & 2.8 & 2.97 & 3.08 & 10.56 & 10.49 & 10.44 & 10.37 & 13.27 & 13.29 & 13.41 & 13.45 \\
\hline 9 & $25 \%$ Stevia $+75 \%$ & 2.89 & 3.00 & 3.18 & 3.29 & 10.46 & 10.41 & 10.34 & 10.26 & 13.35 & 13.41 & 13.52 & 13.55 \\
\hline 10 & $100 \%$ Equal & 3.19 & 3.29 & 3.46 & 3.56 & 10.34 & 10.28 & 10.21 & 10.15 & 13.53 & 13.57 & 13.67 & 13.71 \\
\hline 11 & $75 \%$ Equal + & 2.97 & 3.08 & 3.25 & 3.36 & 10.42 & 10.37 & 10.31 & 10.22 & 13.39 & 13.45 & 13.56 & 13.58 \\
\hline 12 & $\mathbf{5 0 \%}$ Equal + $\mathbf{5 0 \%}$ & 2.44 & 2.51 & 2.60 & 2.72 & 10.71 & 10.68 & 10.65 & 10.57 & 13.15 & 13.19 & 13.25 & 13.29 \\
\hline 13 & $25 \%$ Equal $+75 \%$ & 2.78 & 2.88 & 3.05 & 3.16 & 10.52 & 10.45 & 10.38 & 10.33 & 13.30 & 13.33 & 13.43 & 13.49 \\
\hline 14 & $50 \%$ Erythritol + & 3.34 & 3.43 & 3.6 & 3.70 & 10.29 & 10.23 & 10.17 & 10.09 & 13.63 & 13.66 & 13.77 & 13.79 \\
\hline 15 & $50 \%$ Erythritol + & 3.4 & 3.48 & 3.67 & 3.76 & 10.28 & 10.21 & 10.13 & 10.06 & 13.68 & 13.69 & 13.8 & 13.82 \\
\hline 16 & $50 \%$ Stevia $+50 \%$ & 3.45 & 3.54 & 3.72 & 3.82 & 10.26 & 10.19 & 10.11 & 10.04 & 13.71 & 13.73 & 13.83 & 13.86 \\
\hline & SEm \pm & 0.01 & 0.010 & 0.010 & 0.009 & 0.009 & 0.010 & 0.011 & 0.012 & 0.0105 & 0.009 & 0.011 & 0.008 \\
\hline & CD at $5 \%$ & 0.03 & 0.030 & 0.029 & 0.028 & 0.028 & 0.029 & 0.032 & 0.035 & 0.030 & 0.027 & 0.032 & 0.024 \\
\hline
\end{tabular}

DAT $=$ Days After Treatments 
Table.3 Effect of alternative sweeteners on organoleptic parameters of jamun RTS

\begin{tabular}{|c|c|c|c|c|c|c|c|c|c|c|c|c|c|c|c|c|c|}
\hline \multirow[b]{2}{*}{$\begin{array}{l}\text { S. } \\
\mathbf{N}\end{array}$} & \multirow[b]{2}{*}{ Treatments } & \multicolumn{4}{|c|}{ Colour and appearances } & \multicolumn{4}{|c|}{ Aroma } & \multicolumn{4}{|c|}{ Taste } & \multicolumn{4}{|c|}{ Overall acceptability } \\
\hline & & $\mathbf{0}$ & 30 & 60 & 90 & $\mathbf{0}$ & 30 & 60 & 90 & $\mathbf{0}$ & 30 & 60 & 90 & $\mathbf{0}$ & 30 & 60 & 90 \\
\hline 1 & $100 \%$ Sugar & 8.06 & 7.98 & 7.86 & 7.72 & 7.66 & 7.63 & 7.51 & 7.36 & 8.05 & 7.9 & 7.75 & 7.54 & 7.92 & 7.83 & 7.71 & 7.54 \\
\hline 2 & $100 \%$ Erythritol & 7.52 & 7.44 & 7.39 & 7.17 & 7.24 & 7.2 & 7.13 & 6.99 & 7.58 & 7.54 & 7.41 & 7.17 & 7.44 & 7.39 & 7.31 & 7.11 \\
\hline 3 & 75\% Erythritol + & 7.71 & 7.62 & 7.47 & 7.23 & 7.32 & 7.28 & 7.21 & 7.07 & 7.68 & 7.63 & 7.48 & 7.23 & 7.57 & 7.51 & 7.38 & 7.17 \\
\hline 4 & $50 \%$ Erythritol + & 7.97 & 7.91 & 7.8 & 7.65 & 7.57 & 7.54 & 7.47 & 7.3 & 7.93 & 7.87 & 7.71 & 7.5 & 7.82 & 7.77 & 7.66 & 7.48 \\
\hline 5 & $25 \%$ Erythritol + & 7.85 & 7.77 & 7.60 & 7.42 & 7.47 & 7.42 & 7.36 & 7.21 & 7.77 & 7.73 & 7.55 & 7.31 & 7.69 & 7.64 & 7.5 & 7.31 \\
\hline 6 & $100 \%$ Stevia & 7.32 & 7.19 & 7.13 & 7.03 & 7.13 & 7.05 & 6.96 & 6.82 & 7.44 & 7.25 & 7.14 & 6.88 & 7.29 & 7.16 & 7.07 & 6.91 \\
\hline 7 & $75 \%$ Stevia $+25 \%$ & 7.62 & 7.54 & 7.45 & 7.22 & 7.31 & 7.27 & 7.19 & 7.05 & 7.63 & 7.57 & 7.45 & 7.2 & 7.52 & 7.46 & 7.36 & 7.15 \\
\hline 8 & $\mathbf{5 0 \%}$ Stevia $+\mathbf{5 0 \%}$ & 7.95 & 7.9 & 7.78 & 7.58 & 7.52 & 7.49 & 7.44 & 7.24 & 7.81 & 7.76 & 7.68 & 7.47 & 7.76 & 7.71 & 7.63 & 7.43 \\
\hline 9 & $25 \%$ Stevia $+75 \%$ & 7.82 & 7.75 & 7.58 & 7.36 & 7.44 & 7.4 & 7.34 & 7.19 & 7.75 & 7.71 & 7.54 & 7.27 & 7.67 & 7.62 & 7.48 & 7.27 \\
\hline 10 & $100 \%$ Equal & 7.6 & 7.55 & 7.46 & 7.27 & 7.27 & 7.23 & 7.16 & 7.01 & 7.61 & 7.56 & 7.43 & 7.19 & 7.49 & 7.44 & 7.35 & 7.15 \\
\hline 11 & $75 \%$ Equal + & 7.8 & 7.74 & 7.58 & 7.29 & 7.4 & 7.37 & 7.32 & 7.14 & 7.72 & 7.67 & 7.51 & 7.25 & 7.64 & 7.59 & 7.47 & 7.22 \\
\hline 12 & $\mathbf{5 0 \%}$ Equal $+\mathbf{5 0 \%}$ & 8.13 & 8.06 & 7.96 & 7.76 & 7.69 & 7.64 & 7.54 & 7.38 & 8.11 & 7.96 & 7.81 & 7.61 & 7.97 & 7.88 & 7.77 & 7.58 \\
\hline 13 & $25 \%$ Equal $+75 \%$ & 7.87 & 7.81 & 7.66 & 7.47 & 7.5 & 7.46 & 7.41 & 7.23 & 7.78 & 7.74 & 7.6 & 7.4 & 7.71 & 7.67 & 7.52 & 7.36 \\
\hline 14 & $50 \%$ Erythritol + & 7.47 & 7.33 & 7.28 & 7.13 & 7.22 & 7.17 & 7.1 & 6.94 & 7.54 & 7.49 & 7.38 & 7.14 & 7.41 & 7.33 & 7.25 & 7.07 \\
\hline 15 & $50 \%$ Erythritol + & 7.43 & 7.25 & 7.21 & 7.10 & 7.21 & 7.14 & 7.06 & 6.93 & 7.51 & 7.35 & 7.25 & 6.99 & 7.38 & 7.24 & 7.17 & 7.01 \\
\hline 16 & $50 \%$ Stia $+\mathbf{5 0 \%}$ & 7.37 & 7.23 & 7.18 & 7.08 & 7.17 & 7.09 & 7.02 & 6.86 & 7.48 & 7.31 & 7.21 & 6.96 & 7.34 & 7.21 & 7.13 & 6.96 \\
\hline & SEm \pm & 0.01 & 0.01 & 0.00 & 0.01 & 0.00 & 0.01 & 0.00 & 0.01 & 0.01 & 0.01 & 0.01 & 0.00 & 0.01 & 0.009 & 0.01 & 0.00 \\
\hline & CD at $5 \%$ & $\mathbf{0 . 0 3}$ & 0.03 & 0.02 & 0.02 & 0.02 & 0.02 & 0.02 & 0.03 & 0.03 & 0.03 & 0.02 & $\mathbf{0 . 0 2}$ & $\mathbf{0 . 0 3}$ & $\mathbf{0 . 0 2 7}$ & 0.03 & 0.02 \\
\hline
\end{tabular}


The significantly minimum score was recorded with the treatment $100 \%$ Stevia. There are certain biochemical changes which occurs under low $\mathrm{pH}$ and high temperature that leads to the formation of brown pigments and produces off flavour in the beverages. The other possible reasons could be the loss of volatile aromatic substances responsible for flavour and taste which decreased acceptability in storage at ambient condition.

The present findings are in accordance with the view of Gehlot et al., (2007) who reported that the colour and appearance, flavour, taste and overall acceptability of jamun beverages decreased significantly with the advancement in storage period, however, their overall rating remained above the acceptable level even after three months storage. Upale (2010) reported that the organoleptic scores for taste of RTS jamun were the highest in recipe consisting of 16 per cent juice (with sodium benzoate) +0.15 per cent citric acid adjusted to 16 per cent TSS respectively. Similar findings were also reported by Pandeyand Singh (1998) for guava squash in which there was a gradual decrease in the organoleptic quality and it was found acceptable upto six months.

\section{Overall acceptability}

The score for overall acceptability of jamun RTS affected by different treatments were recorded at $0,30,60$ and 90 days and observed that organoleptic score for overall acceptability continuously decreased with increase in upto 90 days of storage. At the time of preparation, significantly maximum mean score (7.97) was recorded with the treatment $50 \%$ Equal $+50 \%$ Sugar followed by $100 \%$ Sugar and $50 \%$ Erythritol $+50 \%$ Sugar. The significantly minimum score (7.29) was recorded with the treatment $100 \%$ Stevia. After 30, 60 and 90 days of storage, significantly maximum score for overall acceptability was recorded with the treatment $50 \%$ Equal $+50 \%$ sugar. It was significantly minimum with the treatment $100 \%$ Stevia in Table 3. There was a considerable decrease in sensory mean score for colour and appearance, taste, flavour and overall acceptability during storage. The sensory mean score for each attribute was highest on the day of preparation, which decreased with increasing period of storage. There are many extrinsic factors which determine the storage stability of products and temperature plays an important role among them. There are certain biochemical changes which occurs under low $\mathrm{pH}$ and high temperature that leads to formation of brown pigment and produces off flavour in the beverages. The other possible reasons could be the loss of volatile aromatic substances responsible for flavour and taste which decreased acceptability in storage at ambient condition. The present findings are in accordance with the view of Sasikumar (2013) in which there was a gradual decrease in organoleptic score of aloe vera and aonla blend RTS beverages.

\section{References}

AOAC (2002).Official Method of Analysis. $16^{\text {th }}$ Edition Association of Official Analytical Washington DC.

Baramanray, A., Gupta, O.P. and Dhawan, S.S. (1995). Evaluation of guava (Psidium guajava L.) hybrids for making nectar. Haryana J. Hort. Sci., 24(2): 102-109.

Byanna, C.N. andGowda, I.N.D. (2012).Studies on standardization of RTS beverage production from sweet orange and storage. Crop Research, 44(1/2): 102-108.

Chattopadhyay, P., Chatterjee, S. and Sen, S.K. (2008). Biotechnological potentials of natural food grade colourants. Afr. J. Biotechnol., 7: 2972-2985. 
Das, J.N. 2009.Studies on storage stability of jamun beverages. Indian J. Hort., 66(4): 508-510.

Gehlot, S.R., Singh, R. and Yadav, B.S. (2008).Studies on development and quality evaluation of jamun (Syzygium cumini L.) ready-to-serve (RTS) drink and nectar during storage. Haryana $J$. Hort., Sci., 37(1/2): 73-75.

Gehlot, S.R., Singh, R. and Yadav, B.S. (2010).Changes in chemical constituents and overall acceptability of jamun ready-to-serve (RTS) drink and nectar during storage. Haryana $J$. Hort. Sci., 39(1/2): 142-144.

Gaikwad, K. K., Singh, S. and Shakya, B. R. (2012). Studies on the development and shelf life of low calorie herbal aonla-ginger RTS beverage by using artificial sweeteners. J. Food. Processing and Technol., 4(1):200.

Kannan, S. and Thirumaran, A. S. (2002).Studies on the storage life ofJamun (Syzgium cuminii L) fruit products. J. Food Science and Technology. 41(2):186-188.

Kumar, K., Sharma A, and Barmanray, A. (2008).Storage stability of musambi (Citrus sinensis) RTS Beverages in different storage conditions. Beverages and food Beverages World. 35:47-48.

Livesey G. (2006). Glycaemic response and toleration. In: O'Brien-Nabors L editor. Alternative Sweeteners. $4^{\text {th }}$ ed. Florida: CRC Press. p.1-15.

Mall, P. and Tondon, D.K. (2007). Development of guava-aonla blended beverage. Acta Horticulturae, 735:555-560.

Maguire, A. (2006). Dental health. In: Mitchell $\mathrm{H}$ editor. Sweeteners and Sugar Alternatives in Food Technology. Iowa: Blackwell Publishing Ltd. Pp. 19-35.

Gehlot, N. R., Singh R., Rana M.K. (2007).
Changes in chemical components of RTSbael- guava blended beverages during storage, J. Food Sci. Technol 45 (2008) 378-380.

Prince, P.S.M., Kamalakkanan, N. and Menon, V.P. (2003). Syzygium Cuminii Skeels seed extracts reduce tissue damage in diabetic rat brain. $J$. Anthropol., 84: 205-209

Pandey, A.K. (2004). Study about the storage stability of guava beverages. Prog. Hort., 36(1): 142-145.

Patil, U.P. (2001). Studies on extraction and preservation of jamun juice. M.Sc. (Agri.) Thesis, Mahatma Phule Krishi Vidyapeeth, Rahuri, (M.S.), India.

Phalke, S.V. (2009). Blending of sapota and lime juice using different methods of extraction. M.Sc. (Agri.) Thesis, Dr. Panjabrao Deshmukh Krishi Vidyapeeth, Akola (M.S.), India.

Patil, R.M., Chikkasubbanna, V., Thipaana, K.S. and Prashanth, S.J. (2014). Physico-chemical character, sensory quality and storage behaviour of rose apple RTS blended with jamun. Int. J. Processing and Post Harvest Technology, 5(1): 71-75.

Pandey, A.K. and Singh, I.S. (1998).Studies on preparation and preservation of guava squash. Prog. Hort., 30(3-4): 190-193.

Ranganna, S.(1997). Hand book of analysis and quality control for fruit and vegetable products. Tata McGraw Hill Publishing Co. Ltd., New Delhi..

Sharma, S., Mehta, B.K., Mehta, D., Nagar, H. and Mishra, A. (2012). A review on pharmacological activity of Syzygium cumini extracts using different solvent and their effective doses. Int Res. J. Pharm., 3: 54-58.

Saravanan, K., Godara, R.K., Goyal, R.K. and Sharma, R.K. (2004). Processing of papaya fruit for the preparation of ready-to-serve beverage and its 
quality. Indian J. Hill Farming, 17(1/2): 49-55.

Sharma, M., Gehlot, R., Singh, R. and Siddiqui, S. (2009). Changes in chemical constituents of guava-jamun blends ready-to-serve drink and squash during storage. Haryana $J$. Hort. Sci., 38(3/4): 259-263.

Sasikumar, R. (2013). Effect of processing on physiochemical and sensory parameters of low calorie therapeutic RTS beverage blend of Aloe Vera and Aonla fruit using artificial sweeteners. Asian. J. Food Ag-Ind., 6(06):337346.

Upale, K., Patil, R.C., Kamble, A.K., Raut,
N.B. and Kuknoor, L. (2010). Standardization of recipes for readyto-serve (RTS) Jamun beverages. $J$. Ecobiology, 27(3/4): 213-216.

Verma, S. and Gehlot, R. (2006). Development and evaluation of bael beverages. Haryana J. Hort. Sci., 35(3/4): 245-248.

Yadav, A., Chandra, S., Singh, J. and Kumar, V. (2012). Effect of storage conditions on physico-chemical, microbial and sensory quality of ready-to-serve banana beverage. Madras Agril. J.,100(1/3): 251-256.

\section{How to cite this article:}

Bhawna Panda, H.G. Sharma and Abhay Bisen. 2019. Recipe Standardization and Storability of Jamun RTS with Alternative Sweetners. Int.J.Curr.Microbiol.App.Sci. 8(01): 1731-1742. doi: https://doi.org/10.20546/ijcmas.2019.801.184 